\title{
PENGARUH LINGKUNGAN SEKOLAH, DISIPLIN KERJA DAN KEPEMIMPINAN KEPALA SEKOLAH TERHADAP KINERJA GURU SMK N 4 PADANG (Studi Kasus Pada SMK N 4 PADANG) Silvia Iskandar \\ Universitas Putra Indonesia YPTK Padang, Indonesia \\ silviaiskandar12@gmail.com
}

\begin{abstract}
ABSTRAK
Masalah dalam penelitian ini adalah "Kinerja Guru SMK N 4 Padang. Adapun variabel dari penelitian ini adalah Lingkungan Sekolah, Disiplin Kerja, Kepemimpinan Kepala Sekolah (sebagai variabel bebas) dan Kinerja Guru (sebagai variabel terikat). Penelitian ini bertujuan untuk mengetahui pengaruh : (1) Lingkungan Sekolah, Disiplin Kerja dan Kepemimpinan Kepala Sekolah secara bersama-sama terhadap Kinerja Guru, (2) Lingkungan Sekolah, Disiplin Kerja dan Kepemimpinan Kepala Sekolah secara parsial terhadap Kinerja Guru. Sampel penelitian ini adalah para Guru SMK N 4 Padang. Teknik pengambilan sampel adalah dengan purposive sampling dengan jumlah responden 40 orang. Data dalam penelitian ini adalah data primer. Data dikumpulkan dengan menggunakan kuesioner yang dibagikan langsung kepada responden. Metode analisa yang digunakan adalah model regresi linear berganda untuk menguji hipotesis secara simultan dengan uji $\mathrm{F}$ serta untuk menguji hipotesis secara parsial dengan uji t. Hasil dari pengujian hipotesis disimpulkan bahwa secara bersama-sama dan parsial terdapat pengaruh positif dan signifikan dari variabel Lingkungan Sekolah, Disiplin Kerja dan Kepemimpinan Kepala Sekolah terhadap Kinerja Guru. Sehingga hipotesis yang diajukan terbukti/ diterima dalam penelitian ini. Dan disarankan untuk dapat mempertahankan dan meningkatkan Lingkungan Sekolah, Disiplin Kerja dan Kepemimpinan Kepala Sekolah yang telah dicapai dan yang relative sudah baik sehingga Kinerja Guru akan semakin meningkat.
\end{abstract}

Keyword : Lingkungan Sekolah, Disiplin Kerja, Kepemimpinan Kepala Sekolah, Kinerja Guru

\section{PENDAhuluan}

Guru merupakan elemen kunci dalam sistem pendidikan, khususnya di sekolah. Sekolah sebagai sebuah organisasi memiliki peranan yang besar dalam upaya peningkatan mutu pendidikan yang akan berdampak pada kualitas manusia secara menyeluruh. Sekolah sebagai lembaga pendidikan pada hakikatnya merupakan usaha memanusiakan manusia. Keberhasilan dan kegagalan suatu proses pendidikan secara umum dapat dinilai dari outputnya, yaitu orang-orang sebagai produk pendidikan. Semua komponen lain, mulai dari kurikulum, sarana-prasarana, biaya, dan sebagainya tidak akan banyak berarti apabila esensi pembelajaran yaitu interaksi guru dengan peserta didik tidak berkualitas. Semua komponen lain, terutama kurikulum akan "hidup" apabila dilaksanakan oleh guru (Depdiknas, 2008 : 1). Oleh karena itu, dunia pendidikan perlu diperbaiki secara terus-menerus dan berkesinambungan, tidak hanya subyek didiknya, metode pengajaran kurikulum dan segi-segi lain yang mendukung tercapainya maksud dan tujuan pendidikan dan bahkan juga menyangkut kemampuan guru dalam mengajar.

Keberhasilan sistem pendidikan nasional dilihat dari kinerja guru. Kinerja adalah hasil kerja yang dicapai oleh seorang pegawai dalam melaksanakan tugasnya sesuai dengan tanggung jawab yang diberikan kepadanya (Mangkunegara, 2009 : 67). Kinerja guru pada dasarnya merupakan kinerja atau ujuk kerja yang 
dilakukan oleh guru dalam melaksanakan tugasnya sebagai pendidik. Sumber daya manusia guru akan sangat menentukan pada kualitas hasil pendidikan, karena guru merupakan pihak yang paling banyak bersentuhan langsung dengan siswa dalam proses pendidikan atau pembelajaran dilembaga pendidikan sekolah. Untuk itu, guru diharapakan dapat mengelola kinerja dalam upaya mencapai tujuan secara efektifitas dan efisien. Kedisipinan guru sangat perlu dalam menjalankan tugas dan kewajibannya sebagai pengajar, pendidik dan pembimbing siswa. Disiplin yang tinggi akan mampu membangun kinerja yang profesional sebab dengan pemahaman disiplin yang baik, guru akan mampu mencermati aturan-aturan dan langkah strategis dalam melaksanakan proses kegiatan belajar mengajar. Disiplin adalah suatu kondisi yang tercipta dan terbentuk melalui proses dari serangkaian perilaku yang menunjukkan nilai-nilai ketaatan, kepatuhan, kesetiaan, ketentraman, keteraturan, dan ketertiban (Prijodarminto, dalam Sudrajat, 2008 : 213). Nilai-nilai tersebut diupayakan tertanam kuat pada diri setiap guru sehingga menjadi sebuah karakter yang akan menjiwai mereka dalam bekerja. Sedangkan kepemimpinan kepala sekolah memainkan peranan penting dalam upaya peningkatan kualitas kinerja guru. Dalam proses belajar mengajar kepemimpinan adalah suatu bentuk kegiatan dalam kehidupan yang mengandung maksud mempengaruhi orang lain agar bersedia secara bersama-sama untuk mencapai tujuan yang telah ditentukan berdasarkan tujuan pendidikan. Indrafachrudi \& Tahalele, (1995 : 7) berpendapat bahwa kepemimpinan adalah proses mengarahkan, membimbing, mempengaruhi, mengawasi pemikiran, perasaan atau tindakan dan tingkah laku orang lain. Dengan kepemimpinan kepala sekolah yang baik akan tercipta komitmen kerja bagi guru dalam melaksanakan tugasnya, karena kepala sekolah mempunyai peranan yang besar dalam menciptakan komitmen. Jadi hubungan kepemimpinan dengan kinerja guru dalam bertugas sangat erat.

Dalam kaitannya dengan disiplin kerja, kenyataan menunjukkan bahwa guru belum sepenuhnya memiliki kedisiplinan sesuai dengan ketentuan. Berdasarkan pengamatan dan data kehadiran dan ketidakhadiran guru SMK N 4 Padang yang penulis peroleh dari SMK N 4 Padang, menunjukkan masih ada guru yang memiliki disiplin kerja rendah. Hal ini dikarenakan masih ada guru datang ke sekolah tidak tepat waktu. Kecenderungan guru hadir di sekolah waktunya ketika akan mulai jam mengajar. Disiplin kerja merupakan upaya pengaturan waktu dalam bekerja yang dilakukan secara teratur dengan mengembangkan aturan yang ada. Kondisi ini dapat dilihat dari data kehadiran dan ketidakhadiran guru SMK N 4 Padang dimana persentase tertinggi guru hadir tepat waktu selama tahun 2012/2013 belum ada yang mencapai $100 \%$ yang tertinggi hanya $86 \%$ yaitu pada bulan Maret dan rata-rata guru hadir tepat waktu dalam tahun ajaran 2012/2013 hanya 79\% yaitu sebanyak 60 orang. Dan data mengenai RPP dapat diketahui bahwa guru yang membuat dan menyerahkan RPP tepat waktu sesuai jadwal yang sudah ditentukan masih di bawah yang diharapkan, ini menunjukkan bahwa kinerja guru di SMK N 4 Padang masih kurang/belum sesuai dengan yang diharapkan dalam ketepatan penyerahan RPP. Dimana persentase tertinggi guru yang menyerahkan RPP sesuai jadwal selama tahun 2011/2012 belum ada yang mencapai $100 \%$ yang tertinggi hanya 53\% yaitu pada semester II/2011. Begitu juga untuk tahun 2012/2013, guru yang menyerahkan RPP belum ada yang mencapai $100 \%$ yang tertinggi hanya 55\% yaitu pada semester I/2013.

Dari kedua fenomena tersebut dapat dinyatakan kinerja guru SMK N 4 Padang belum optimal. Belum optimalnya kinerja guru tersebut disinyalir disebabkan oleh lingkungan sekolah, disiplin dan kepemimpinan. Kinerja yang baik dalam organisasi merupakan sebuah pencapaian akhir tujuan organisasi. Kinerja yang baik berkaitan dari hasil yang dicapai oleh karyawan dalam organisasi yang dapat bersifat baik atau buruk. Sebuah organisasi pasti menginginkan sebuah pencapaian hasil kinerja karyawan yang baik dan sesuai dengan tujuan organisasi. Kinerja guru itu baik atau tidak tergantung faktor yang mempengaruhi kinerja guru tersebut. Faktor yang dapat mempengaruhi kinerja seseorang antara lain mencangkup: daya tarik pekerjaan, disiplin, upah atau insentif, kemauan dan perlindungan kerja, pengetahuan, lingkungan kerja dan suasana atau iklim kerja, harapan pengembangan karir, keterlibatan dalam kegiatan organisasi, perhatian dan kepemimpinan atasan. 


\section{TINJAUAN PUSTAKA 2.1 Lingkungan Sekolah}

Konsep lingkungan kerja menurut Nitisemito, (2003 : 183) mengemukakan "Lingkungan kerja adalah segala yang ada disekitar para pekerja yang dapat mempengaruhi dirinya dalam menjalankan tugas yang dibebankan". Pendapat lain mengatakan "Lingkungan kerja adalah faktor-faktor di luar manusia baik fisik maupun non fisik dalam suatu organisasi (Sihombing, 2004 : 174). Faktor fisik ini mencakup peralatan kerja, suhu tempat kerja, kesesakan dan kepadatan, kebisingan, luas ruang kerja sedangkan non fisik mencakup hubungan kerja yang terbentuk di instansi antara atasan dan bawahan serta antara sesama karyawan". Dari faktor-faktor diatas, dapat dikatakan bahwa lingkungan kerja dapat berpengaruh terhadap pekerjaan yang dilakukan. Karena dengan lingkungan yang sesuai dan menyenangkan serta cocok dengan budaya individu akan dapat memberikan dorongan kepada karyawan untuk bekerja lebih bersemangat, sehingga dengan lingkungan kerja yang menyenangkan tersebut karyawan dapat berprestasi lebih baik.

\subsection{Disiplin Kerja}

Pengertian disiplin menurut Kamus Besar Bahasa Indonesia adalah ketaatan (kepatuhan) kepada peraturan (tata tertib dan sebagainya). Kata disiplin berasal dari bahasa Latin "disciplina" yang berarti latihan atau pendidikan kesopanan dan kerokhanian serta pengembangan tabiat. Disiplin kerja guru menurut Ali Imron (1995 : 183) adalah "Suatu keadaan tertib dan teratur yang dimiliki oleh guru dalam bekerja di sekolah, tanpa ada pelanggaran yang merugikan baik secara langsung maupun tidak langsung terhadap dirinya, teman sejawatnya dan terhadap sekolah secara keseluruhan". Ada beberpa hal yang dapat dipakai sebagai indikasi tinggi rendahnya kedisiplinan kinerja guru yaitu : ketepatan waktu, kepatuhan terhadap atasan, peraturan terhadap prilaku terlarang, ketertiban terhadap peraturan yang berhubungan langsung dengan produktiviatas kerja. Jadi penelitian ini menganalisis nilai-nilai dalam disiplin kerja yaitu mengenai ketepatan waktu dan kepatuhan terhadap atasanya.

\subsection{Kepemimpinan Kepala Sekolah}

Kepemimpinan merupakan kemampuan yang dimiliki seseorang untuk mempengaruhi orang lain, agar dapat bekerja untuk mencapai tujuan dan sasaran. Selanjutnya menurut Irawan (2007 : 165), "Kepemimpinan adalah cara seorang pemimpin mempengaruhi prilaku bawahan agar mau bekerja sama dan bekerja secara produktif untuk mencapai tujuan organisasi. Pemimpin pada hakikatnya adalah seorang yang mempunyai kemampuan untuk mempengaruhi perilaku orang lain di dalam kerjanya dengan menggunakan kekuasaan. Dan dalam kegiatannya, bahwa pemimpin memiliki kekuasaan untuk mengarahkan dan mempengaruhi bawahannya sehubungan dengan tugas-tugas yang harus dilaksanakan.

\subsection{Kinerja Guru}

Kinerja (performance) adalah tingkat prestasi atau hasil nyata yang dicapai dipergunakan untuk memperoleh suatu hasil positif. Kinerja juga didefinisikan sebagai keberhasilan personel dalam mewujudkan sasaran stratejik pada empat perspektif : keuangan, costumer, proses serta pembelajaran dan pertumbuhan. Kinerja merupakan hasil kerja yang dicapai seseorang dalam melaksanakan tugas-tugas yang dibebankan kepadanya didasarkan atas kecakapan, pengalaman, kesungguhan dan waktu. Dengan demikian, kinerja guru berarti hasil kerja atau prestasi seorang guru dalam mengemban tugasnya sebagai seorang pendidik agar dapat memenuhi tujuan dari sekolah tempatnya bekerja. 


\section{METODOLOGI PENELITIAN}

\subsection{Jenis Penelitian}

Jenis penelitian yang digunakan dalam penelitian ini adalah penelitian explanatory research dengan menggunakan metode survey yaitu penelitian yang berusaha menjelaskan pengaruh variabel bebas (independen) terhadap variabel terikat (dependen). Alasan utama menggunakan penelitian explanatory ini adalah berhubungan dengan pemilihan hipotesis yang dilakukan. Melalui uji hipotesis yang dilakukan penulis berharap dapat menjelaskan pengaruh masing-masing atau bersama-sama variabel bebas dengan variabel terikat, sekaligus mengetahui variabel bebas yang paling berpengaruh terhadap variabel terikat. Pelaksanaan lingkungan sekolah merupakan variabel bebas pertama $\left(\mathrm{X}_{1}\right)$, disiplin kerja merupakan variabel bebas kedua $\left(\mathrm{X}_{2}\right)$, dan kepemimpinan kepala sekolah merupakan variabel bebas ketiga $\left(\mathrm{X}_{3}\right)$. Sementara kinerja guru merupakan variabel terikat (Y).

\subsection{Lokasi dan Waktu Penelitian}

Lokasi penelitian akan dilakukan pada SMK N 4 Padang. Pemilihan terhadap lokasi tersebut didasarkan pertimbangan, kemudahan, keterbatasan waktu, tenaga dan biaya dalam penelitian ini. Disamping itu juga kualitas kerja dan karakteristik kelayakan masalah yang sangat memungkinkan untuk mendapatkan informasi yang akan menunjang tercapainya tujuan penelitian. Penelitian ini direncanakan pada bulan Mei 2014 s/d Juli 2014.

\subsection{Populasi Penelitian}

Populasi adalah keseluruhan objek yang akan diteliti. Populasi dalam penelitian ini adalah seluruh guru pada SMK N 4 Padang yang berjumlah 58 orang.

\subsection{Instrumen Penelitian}

Instrumen penelitian ini berupa kuesioner atau angket yang diajukan kepada para responden yaitu Guru SMK N 4 Padang untuk memberikan jawaban atas pertanyaan yang diajukan dengan memilih salah satu jawaban yang dianggap sesuai dengan kenyataan atau keadaan yang sebenarnya yang terjadi pada responden. Jawaban yang diberikan oleh responden masih kualitatif selanjutnya akan diukur secara kuantitatif dengan skala likert 1 sampai 5. Kuesioner merupakan pertanyaan yang sudah diformulasikan secara tertulis untuk mendapatkan jawaban dari responden. Kuesioner dibuat berdasarkan penelitian sebelumnya.

\subsection{Definisi Operasional dan Pengukuran Variabel}

\subsubsection{Lingkungan Sekolah $\left(\mathrm{X}_{1}\right)$}

Lingkungan kerja adalah segala sesuatu yang ada disekitar karyawan pada saat bekerja baik pada lingkungan fisik maupun non fisik baik secara langsung maupun tidak langsung dapat mempengaruhi dirinya dan pekerjaanya saat bekerja. Lingkungan sekolah $\left(\mathrm{X}_{1}\right)$ sebagai variabel independen (bebas), data tentang lingkungan sekolah diperoleh melalui angket yang diisi oleh guru yang menjadi responden. Angket ini disusun berdasarkan indikator-indikator lingkungan kerja sebagai berikut : (1) lingkungan fisik, dan (2) lingkungan non fisik. 


\subsubsection{Disiplin Kerja $\left(\mathbf{X}_{2}\right)$}

Disiplin kerja adalah suatu sikap tingkah laku dan perbuatan yang sesuai dengan peraturan dari sekolah baik tertulis maupun tidak tertulis. Disiplin kerja $\left(\mathrm{X}_{2}\right)$ sebagai variabel independen (bebas), data tentang disiplin diperoleh melalui angket yang diisi oleh guru yang menjadi responden. Angket ini disusun berdasarkan indikator-indikator disiplin kerja sebagai berikut : (1) kedisiplinan terhadap jam kerja, (2) kedisiplinan terhadap peraturan dan tata tertib dan (3) kedisiplinan terhadap peningkatan kerja sama.

\subsubsection{Kepemimpinan Kepala Sekolah $\left(\mathbf{X}_{3}\right)$}

Kepemimpinan merupakan kemampuan yang dimiliki seseorang untuk mempengaruhi orang lain agar bekerja sama mencapai tujuan dan sasaran. Kepemimpinan kepala sekolah $\left(\mathrm{X}_{3}\right)$ sebagai variabel independen (bebas), data tentang kepemimpinan kepala sekolah diperoleh melalui angket yang diisi oleh para guru yang menjadi responden.Akuntabilitas adalah variabel independen kedua dalam penelitian ini. Angket disusun berdasarkan indikator-indikator yaitu : (1) kemampuan pemimpin dalam menjalin hubungan dengan bawahan, (2) kemampuan pemimpin dalam mendelegasikan kewenangannya kepada bawahan, (3) kemampuan pemimpin dalam menerima saran dari bawahan, (4) kemampuan pemimpin dalam membantu mengatasi kesulitan bawahan, (5) kemampuan pemimpin dalam menerima perubahan yang terjadi dalam pelaksanaan pekerjaan.

\subsubsection{Kinerja Guru (Y)}

Kinerja guru adalah merupakan hasil kerja seorang guru dalam melaksanakan tugasnya sebagai seorang pendidik untuk menghasilkan anak didik yang berkualitas guna tercapainya tujuan pendidikan dan memenuhi tujuan dari sekolah tempatnya bekerja. Kinerja guru ini disebut juga dengan variabel dependen (terikat) (Y).indikatornya adalah : (1) perencanaan program kegiatan pembelajaran, (2) pelaksanaan kegiatan pembelajaran, (3) penilaian/ evaluasi hasil belajar.

\section{HASIL DAN PEMBAHASAN}

\subsection{Uji Hipotesis}

\subsubsection{Analisis Regresi Linear Berganda}

Menurut Sekaran (2006 : 213), hipotesis merupakan dugaan tentang hubungan yang logis antara dua variabel atau lebih yang dinyatakan dalam bentuk pernyataan yang perlu diuji kebenarannya. Dari instrumen yang disebarkan kepada 40 orang guru SMK N 4 Padang, diperoleh data yang dapat digunakan untuk menguji hipotesis yang diajukan dalam penelitian ini. Data yang diperoleh diolah dengan SPSS versi 15.0 dengan alat analisi regresi linear berganda.

Tabel 1

Hasil Analisi Regresi Linear Berganda dari Persepsi Responden mengenai Variabel Lingkungan Sekolah, Disiplin Kerja, Kepemimpinan Kepala Sekolah dan pengaruhnya terhadap Kinerja Guru SMK N 4 Padang

\section{Model Summary(b)}

\begin{tabular}{|l|l|r|r|r|}
\hline Model & $\mathrm{R}$ & \multicolumn{1}{|c|}{ R Square } & Adjusted R Square & $\begin{array}{c}\text { Std. Error of the } \\
\text { Estimate }\end{array}$ \\
\hline 1 &, $916(\mathrm{a})$ &, 838 &, 825 & 3,100 \\
\hline
\end{tabular}

a Predictors: (Constant), Kepemimpinan Kepala Sekolah (X3), Lingkungan Sekolah (X1), Disiplin Kerja (x2)

b Dependent Variable: Kinerja Guru (Y)

Sumber : data primer diolah (2014) 


\section{ANOVA(b)}

\begin{tabular}{|ll|r|r|r|r|r|}
\hline $\begin{array}{l}\text { Mod } \\
\mathrm{el}\end{array}$ & & $\begin{array}{r}\text { Sum of } \\
\text { Squares }\end{array}$ & df & Mean Square & F & Sig. \\
\hline 1 & Regression & $\begin{array}{r}1791.51 \\
6\end{array}$ & 3 & 597.172 & 62.159 & $.000(\mathrm{a})$ \\
& Residual & 345.859 & 36 & 9.607 & & \\
& Total & 2137.37 & 39 & & & \\
& & 5 & & & & \\
\hline
\end{tabular}

a Predictors: (Constant), Kepemimpinan Kepala Sekolah (X3), Lingkungan Sekolah (X1), Disiplin Kerja (x2)

b Dependent Variable: Kinerja Guru (Y)

Sumber : data primer diolah (2014)

Coefficients(a)

\begin{tabular}{|c|c|c|c|c|c|c|}
\hline \multicolumn{2}{|c|}{ Model } & \multicolumn{2}{|c|}{$\begin{array}{c}\text { Unstandardized } \\
\text { Coefficients }\end{array}$} & \multirow{2}{*}{$\begin{array}{c}\text { Standardized } \\
\text { Coefficients } \\
\text { Beta }\end{array}$} & \multirow[t]{2}{*}{$\mathrm{t}$} & \multirow[t]{2}{*}{ Sig. } \\
\hline & & B & $\begin{array}{l}\text { Std. } \\
\text { Error }\end{array}$ & & & \\
\hline \multirow[t]{4}{*}{1} & (Constant) & 4.757 & 6.113 & & .778 & .442 \\
\hline & $\begin{array}{l}\text { Lingkungan Sekolah } \\
\text { (X1) }\end{array}$ & .013. & .116 & .009 & .111 & .913 \\
\hline & Disiplin Kerja (x2) & .556 & .101 & .557 & 5.488 & .000 \\
\hline & $\begin{array}{l}\text { Kepemimpinan Kepala } \\
\text { Sekolah (X3) }\end{array}$ & .443 & .108 & .419 & 4.108 & .000 \\
\hline
\end{tabular}

a Dependent Variable: Kinerja Guru (Y)

Sumber : data primer diolah (2014)

\section{Pengujian Hipotesis 1}

Hipotesis pertama yang menyatakan bahwa lingkungan sekolah secara parsial berpengaruh positif dan signifikan terhadap kinerja guru SMK N 4 Padang dapat dilihat dan dibuktikan dari coefficient pada tabel 1 diatas. Dari tabel 1 (Tabel Coefficient) diatas terlihat nilai koefisien regresinya (B) yang bertanda positif yaitu sebesar 0,013 serta nilai t hitung 0,111 lebih kecil dari t tabel $(0,111<1,687)$ atau tingkat signifikan lebih besar dari alpha $(0,913>0,05)$, maka Ha ditolak dan Ho diterima. Artinya, secara parsial ada pengaruh positif tetapi tidak signifikan antara lingkungan sekolah $\left(\mathrm{X}_{1}\right)$ terhadap kinerja guru $(\mathrm{Y})$. Oleh karena itu hipotesis pertama yang menyatakan "lingkungan sekolah secara parsial berpengaruh positif dan signifikan terhadap kinerja guru SMK N 4 Padang" ditolak.

\section{Pengujian Hipotesis 2}

Hipotesis kedua yang menyatakan bahwa disiplin kerja secara parsial berpengaruh positif dan signifikan terhadap kinerja guru SMK N 4 Padang dapat dilihat dan dibuktikan dari coefficient pada tabel 1 diatas. Dari tabel 1 ( Tabel Coefficient) diatas terlihat nilai koefisien regresinya (B) yang bertanda positif yaitu sebesar 0,556 serta nilai t hitung 5,488 lebih besar dari t tabel $(5,488>1,687)$ atau tingkat signifikan lebih kecil dari alpha $(0,000<0,05)$, maka Ho ditolak dan Ha diterima. Artinya, secara parsial ada pengaruh positif dan signifikan antara disiplin kerja $\left(\mathrm{X}_{2}\right)$ terhadap kinerja guru $(\mathrm{Y})$. Oleh karena itu hipotesis kedua yang menyatakan "disiplin kerja secara parsial berpengaruh positif dan signifikan terhadap kinerja guru SMK N 4 Padang" diterima. 


\section{Pengujian Hipotesis 3}

Hipotesis ketiga yang menyatakan bahwa kepemimpinan kepala sekolah secara parsial berpengaruh positif dan signifikan terhadap kinerja guru SMK N 4 Padang dapat dilihat dan dibuktikan dari coefficient pada tabel 1 diatas. Dari tabel 1 ( Tabel Coefficient) diatas terlihat nilai koefisien regresinya (B) yang bertanda positif yaitu sebesar 0,443 serta nilai t hitung 4,108 lebih besar dari t tabel $(4,108>1,687)$ atau tingkat signifikan lebih kecil dari alpha $(0,000<0,05)$, maka Ho ditolak dan Ha diterima. Artinya, secara parsial ada pengaruh positif dan signifikan antara kepemimpinan kepala sekolah $\left(\mathrm{X}_{3}\right)$ terhadap kinerja guru (Y). Oleh karena itu hipotesis ketiga yang menyatakan "kepemimpinan kepala sekolah secara parsial berpengaruh positif dan signifikan terhadap kinerja guru SMK N 4 Padang" diterima.

Berdasarkan tabel 1 (coeffcient) diatas dapat diperoleh persamaan regresinya sebagai berikut :

$$
\begin{aligned}
& \mathrm{Y}=4,757+0,013 \mathrm{X}_{1}+0,556 \mathrm{X}_{2}+0,443 \mathrm{X}_{3} \text { dimana } \\
& \mathrm{Y} \quad=\text { Kinerja Guru } \\
& \mathrm{X}_{1} \quad \text { = Lingkungan Sekolah } \\
& \mathrm{X}_{2} \quad \text { = Disiplin Kerja } \\
& \mathrm{X}_{3} \quad \text { = Kepemimpinan Kepala Sekolah }
\end{aligned}
$$

Hasil persamaan regresi linear berganda tersebut dapat diuraikan sebagai berikut :

a. Nilai konstan sebesar 4,757 menyatakan bahwa jika nilai Lingkungan Sekolah nol, nilai Disiplin Kerja nol dan nilai Kepemimpinan Kepala Sekolah nol maka nilai Kinerja Guru sebesar 4,757 satuan. Dan meskipun variabel Lingkungan Sekolah $\left(\mathrm{X}_{1}\right)$, Disiplin Kerja $\left(\mathrm{X}_{2}\right)$ dan Kepemimpinan Kepala Sekolah $\left(\mathrm{X}_{3}\right)$ dianggap tidak ada atau diabaikan (nilainya $=0$ ) tetapi Kinerja Guru (Y) masih ada nilainya yaitu sebesar 4,757 satuan yang relatif angka tersebut cukup besar dibandingkan koefisien regresi lainnya. Sehingga dapat diperoleh pengertian bahwa didalam lingkungan sekolah di SMK N 4 Padang tersebut telah berjalan selama ini dan para guru memiliki penghayatan yang tinggi atas tugas dan kewajibannya sebagai tenaga-tenaga pendidikan. Sehinnga pencapaian Kinerja Guru di sekolah tersebut pada variabel bebas Lingkungan Sekolah, Disiplin Kerja dan Kepemimpinan Kepala Sekolah dianggap tidak ada sedangkan Kinerja Guru masih memiliki nilai koefisien yang relatif tinggi yaitu 4,757 satuan.

b. Koefisien regresi $X_{1}$ (lingkungan sekolah) sebesar 0,013 berarti lingkungan sekolah memiliki hubungan searah (positif) terhadap kinerja guru. Dengan demikian setiap peningkatan lingkungan sekolah satu satuan akan meningkatkan kinerja guru sebesar 0,013 satuan dan atau dalam keadaan sebaliknya.

c. Koefisien regresi $\mathrm{X}_{2}$ (disiplin kerja) sebesar 0,556 berarti disiplin kerja memiliki hubungan searah (positif) terhadap kinerja guru. Dengan demikian setiap peningkatan disiplin kerja satu satuan akan meningkatkan kinerja guru sebesar 0,556 satuan dan atau dalam keadaan sebaliknya.

d. Koefisien regresi $\mathrm{X}_{3}$ (kepemimpinan kepala sekolah) sebesar 0,443 berarti kepemimpinan kepala sekolah memiliki hubungan searah (positif) terhadap kinerja guru. Dengan demikian setiap peningkatan kepemimpinan kepala sekolah satu satuan akan meningkatkan kinerja guru sebesar 0,443 satuan dan atau dalam keadaan sebaliknya.

\section{Pengujian Hipotesis 4}

Hipotesis keempat menyatakan bahwa lingkungan sekolah, disiplin kerja dan kepemimpinan kepala sekolah secara bersama-sama berpengaruh terhadap kinerja guru SMK N 4 Padang dapat dilihat dan dibuktikan dari model summary pada tabel 1 diatas. 
Dari Model Summary pada tabel 1 diatas diperoleh bahwa koefisien R adalah 0,916 yaitu terdapat hubungan yang kuat antara lingkungan sekolah, disiplin kerja dan kepemimpinan kepala sekolah secara bersama-sama terhadap kinerja guru dan nilai koefisien determinan atau $R$ square/ $R^{2}$ adalah 0,838 yang berarti bahwa kontribusi pengaruh lingkungan sekolah, disiplin kerja dan kepemimpinan kepala sekolah secara bersamasama terhadap kinerja guru adalah sebesar $(83,8 \%)$ dan sisanya $(16,2 \%)$ dipengaruhi oleh faktor lain yang tidak termasuk dalam ruang lingkup penelitian ini.

Untuk mengetahui apakah lingkungan sekolah, disiplin kerja dan kepemimpinan kepala sekolah berpengaruh positif dan signifikan terhadap kinerja guru dapat dilihat dari tabel Anova pada tabel 1. Dari tabel Anova diatas dapat dilihat nilai $\mathrm{F}$ hitung sebesar 62,159 dan lebih besar dari $\mathrm{F}$ tabel yaitu 62,159>2,87 dengan tingkat signifikansi sebesar 0,000 . Jika nilai signifikan dibanding dengan tingkat signifikan yang digunakan pada penelitian ini dengan Alpha 0,05 digunakan $(0,000<0,05)$. Dengan demikian, maka Ho ditolak dan Ha diterima yang berarti lingkungan sekolah $\left(\mathrm{X}_{1}\right)$, disiplin kerja $\left(\mathrm{X}_{2}\right)$, dan kepemimpinan kepala sekolah $\left(\mathrm{X}_{3}\right)$ secara bersama-sama berpengaruh positif dan signifikan terhadap kinerja guru. Oleh karena itu hipotesis keempat yang menyatakan "Lingkungan Sekolah, Disiplin Kerja dan Kepemimpinan Kepala Sekolah secara bersama-sama berpengaruh positif dan signifikan terhadap Kinerja Guru SMK N 4 Padang “ diterima.

\subsection{Pembahasan}

Kinerja guru sangat penting bagi guru dan pihak sekolah sebagai tolak ukur dalam menilai keberhasilanya dalam upaya membina serta memberikan pendidikan bagi siswa-siswanya. Dengan kinerja guru yang baik, siswa akan berhasil dalam studinya dan diharapkan apa yang menjadi cita-citanya dalam bidang pendidikan akan tercapai. Kinerja guru yang baik selalu menjadi tujuan bagi SMK N 4 Padang yang dipengaruhi oleh beberapa variabel berikut :

\subsubsection{Pengaruh Lingkungan Sekolah Terhadap Kinerja Guru}

Berdasarkan hasil pengujian hipotesis pertama, diketahui bahwa lingkungan sekolah berpengaruh positif tetapi tidak signifikan terhadap kinerja guru SMK N 4 Padang. Hal ini dibuktikan dengan melihat nilai signifikasi probability yaitu $0,913>\alpha$ yaitu 0,05 artinya tidak signifikan. Yang berarti keadaan lingkungan sekolah di SMK N 4 Padang sudah baik jadi tinggal bagaimana pihak sekolah yang terdiri dari kepala sekolah dan seluruh warga sekolah untuk tetap mempertahankan keadaan lingkungan sekolah serta meningkatkannya untuk lebih baik lagi sehinnga dapat selalu menciptakan lingkungan sekolah yang kondusif dan menyenangkan sehingga kinerja guru di SMK N 4 Padang akan meningkat. Selain itu juga didapat nilai koefisien regresi yang bertanda positif yang menunjukkan terjadinya hubungan yang searah antara lingkungan sekolah terhadap kinerja guru, sebesar 0,013 artinya lingkungan sekolah yang baik akan meningkatkan kinerja guru SMK N 4 Padang. Dan sebaliknya jika terjadi penurunan nilai lingkungan sekolah maka akan menurunkan kinerja guru sebesar 0,013 satuan. Dengan kata lain, semakin baik lingkungan sekolah SMK N 4 Padang maka akan semakin tinggi kinerja guru di SMK N 4 Padang.

\subsubsection{Pengaruh Disiplin Kerja Terhadap Kinerja Guru}

Berdasarkan hasil pengujian hipotesis kedua, diketahui bahwa disiplin kerja berpengaruh positif dan signifikan terhadap kinerja guru SMK N 4 Padang. Hal ini dibuktikan dengan melihat nilai signifikasi probability yaitu $0,000<\alpha$ yaitu 0,05 artinya signifikan. Selain itu juga didapat nilai koefisien regresi yang bertanda positif yang menunjukkan terjadinya hubungan yang searah antara disiplin kerja terhadap kinerja guru, sebesar 0,556 artinya dengan semakin tinggi disiplin kerja yang diterapkan di lingkungan SMK N 4 Padang maka akan semakin tinggi kinerja guru di SMK N 4 Padang. Dan sebaliknya jika terjadi penurunan nilai disiplin kerja maka akan menurunkan kinerja guru sebesar 0,556 satuan. Oleh karena itu, tindakan disiplin yang efektif dapat mendorong guru untuk meningkatkan kinerjanya. Sehingga dapat dikatakan adanya hubungan yang signifikan dan positif antara disiplin kerja dengan kinerja guru. 


\subsubsection{Pengaruh Kepemimpinan Kepala Sekolah Terhadap Kinerja Guru}

Berdasarkan hasil pengujian hipotesis ketiga, diketahui bahwa kepemimpinan kepala sekolah berpengaruh positif dan signifikan terhadap kinerja guru SMK N 4 Padang. Hal ini dibuktikan dengan melihat nilai signifikasi probability yaitu $0,000<\alpha$ yaitu 0,05 artinya signifikan. Selain itu juga didapat nilai koefisien regresi yang bertanda positif yang menunjukkan terjadinya hubungan yang searah antara kepemimpinan kepala sekolah terhadap kinerja guru, sebesar 0,443 artinya kepemimpinan yang baik akan meningkatkan kinerja guru SMK N 4 Padang. Hal ini bermakna bila fungsi kepemimpinan dapat diimplementasikan lebih baik maka akan dapat meningkatkan kinerja guru SMK N 4 Padang. Dengan kata lain, semakin baik fungsi kepemimpinan yang diterapkan dilingkungan SMK N 4 Padang, maka akan semakin tinggi kinerja guru SMK N 4 Padang. Dan sebaliknya jika terjadi penurunan nilai kepemimpinan maka akan menurunkan kinerja guru sebesar 0,443 satuan. Kepemimpinan tersebut melingkupi kemampuan pemimpin dalam menjalin hubungan dengan bawahan, dalam mendelegasikan kewenangannya kepada bawahan, dalam menerima saran dari bawahan, dalam membantu mengatasi kesulitan bawahan dan dalam menerima perubahan yang terjadi dalam pelaksanaan pekerjaan. Bila pemimpin di lingkungan SMK N 4 Padang lebih mampu melakukan hal tersebut diatas, maka kondisi ini diharapkan akan mampu meningkatkan kinerja guru SMK N 4 Padang dimasa yang akan datang.

\subsubsection{Pengaruh Lingkungan Sekolah, Disiplin Kerja dan Kepemimpinan Kepala Sekolah Terhadap Kinerja Guru}

Hasil penelitian menemukan bahwa secara bersama-sama terdapat pengaruh positif dan signifikan antara lingkungan sekolah, disiplin kerja dan kepemimpinan kepala sekolah terhadap kinerja guru SMK N 4 Padang artinya, semakin baik lingkungan sekolah, disiplin kerja dan kepemimpinan kepala sekolah maka akan semakin baik pula kinerja guru SMK N 4 Padang. Sumbangan pengaruh secara bersama-sama antara variabel lingkungan sekolah, disiplin kerja dan kepemimpinan kepala sekolah terhadap kinerja guru sebesar 83,8\% dan 16,2\% lainnya dipengaruhi oleh variabel lain yang tidak diteliti seperti iklim sekolah, motivasi, budaya organisasi, pendidikan, pengembangan karier, supervisi, etos kerja, komitmen, kompetensi dan lainlainnya.

Dan dari ketiga variabel yang diteliti tersebut yang paling berpengaruh terhadap kinerja guru dari hasil penelitian yang telah dilakukan adalah disiplin kerja karena disiplin kerja memiliki nilai koefisien regresi (B) yang yang paling besar dan bertanda positif yaitu sebesar 0,556 sedangkan variabel kedua yang paling berpengaruh terhadap kinerja guru adalah variabel kepemimpinan kepala sekolah dengan nilai koefisien regresinya (B) yang bertanda positif sebesar 0,443 sedangkan untuk variabel lingkungan sekolah dengan nilai koefisien regresinya (B) sebesar 0,013 .

Lingkungan sekolah memiliki pengaruh yang besar terhadap kinerja guru, karena dengan lingkungan sekolah yang baik, baik secara fisik maupun non fisik akan menciptakan suasana mengajar yang kondusif serta hubungan yang harmonis bagi semua warga sekolah sehingga akan meningkatkan kinerja guru dan meningkatkan kualitas hasil belajar para peserta didiknya. Disiplin kerja juga berpengaruh pada kinerja guru, karena dengan disiplin seorang guru akan disiplin terhadap jam kerja, mematuhi dan mentaati peraturan dan tata tertib dan disiplin pada peningkatan kerjasama. Selain itu, kepemimpinan kepala sekolah juga memiliki pengaruh yang besar terhadap kinerja guru, karena dengan kepemimpinan yang baik seorang guru akan melaksanakan apa yang sudah ditetapkan dengan senang hati, dan meningkatkan kerjasaman sesama guru sehingga akan terjalin kerjasama yang baik serta terciptanya hubungan yang baik antar sesama warga sekolah. 


\section{KESIMPULAN}

Penelitian ini meneliti tentang pengaruh Lingkungan Sekolah, Disiplin Kerja Dan Kepemiminan Kepala Sekolah terhadap Kinerja Guru di SMK N 4 Padang. Berdasarkan pengolahan data dan analisis yang telah dilakukan, maka dapat diambil beberapa kesimpulan sebagai berikut : (1) Variabel lingkungan sekolah berpengaruh positif tetapi tidak signifikan terhadap kinerja guru SMK N 4 Padang, dengan nilai koefisien regresinya (B) yang bertanda positif yaitu sebesar 0,013 serta nilai $\mathrm{t}$ hitung lebih kecil dari $\mathrm{t}$ tabel $(0,111<1,687)$ dan tingkat signifikan lebih besar dari alpha $(0,913<0,05)$. Dengan lingkungan yang sesuai dan menyenangkan serta cocok dengan budaya individu akan dapat memberikan dorongan kepada guru untuk bekerja lebih bersemangat dan dapat meningkatkan kinerja guru. (2) Variabel disiplin kerja berpengaruh positif dan signifikan terhadap kinerja guru SMK N 4 Padang. Dan disiplin kerja merupakan variabel yang paling berpengaruh dibandingkan dengan kedua variabel lainnya karena memiliki nilai koefisien regresi (B) yang paling besar dan bertanda positif yaitu sebesar 0,556 serta nilai t hitung lebih besar dari t tabel $(5,488>1,687)$ dan tingkat signifikan lebih kecil dari alpha $(0,000<0,05)$. Dengan disiplin kerja yang tinggi akan dapat meningkatkan kinerja guru. (3) Variabel kepemimpinan kepala sekolah berpengaruh positif dan signifikan terhadap kinerja guru SMK N 4 Padang. Dan kepemimpinan kepala sekolah merupakan variabel kedua yang paling berpengaruh dengan nilai koefisien regresinya (B) yang bertanda positif yaitu sebesar 0,443 serta nilai t hitung lebih besar dari t tabel $(4,108>1,687)$ dan tingkat signifikan lebih kecil dari alpha $(0,000<0,05)$. Dengan kepempiminan kepala sekolah yang baik yang dapat memimpin dan mengarahkan guru dengan baik maka akan dapat meningkatkan kinerja guru. (4) Variabel lingkungan sekolah, disiplin kerja dan kepemimpinan kepala sekolah berpengaruh positif dan signifikan terhadap kinerja guru SMK N 4 Padang yang hasilnya dapat dilihat pada tabel 1 yaitu pada tabel anova dimana nilai signifikansinya sebesar 0,000 yang mana lebih keci dari $\alpha 0,05$. Dan pada tabel model summary dimana nilai koefisien determinasinya $\left(\mathrm{R}^{2}\right)$ sebesar $83,8 \%$, sedangkan sisanya sebesar $16,2 \%$ dikonstribusi oleh variabel lain yang tidak termasuk kedalam ruang lingkup penelitian ini, dimana variabel yang paling menentukan atau mempengaruhi kinerja guru adalah disiplin kerja. (5) Dan dari ketiga variabel yang diteliti tersebut yang paling berpengaruh terhadap kinerja guru dari hasil penelitian yang telah dilakukan adalah disiplin kerja karena disiplin kerja memiliki nilai koefisien regresi (B) yang yang paling besar dan bertanda positif yaitu sebesar 0,556 sedangkan variabel kedua yang paling berpengaruh terhadap kinerja guru adalah variabel kepemimpinan kepala sekolah dengan nilai koefisien regresinya (B) yang bertanda positif sebesar 0,443 sedangkan untuk variabel lingkungan sekolah dengan nilai koefisien regresinya (B) sebesar 0,013.

Berdasarkan hasil penelitian yang diperoleh maka untuk meningkatkan Kinerja Guru di SMK N 4 Padang disarankan beberapa hal sebagai berikut : (1) Agar lebih meningkatkan variabel-variabel bebas yang telah dilteli dalam penelitian ini. Dimana variabel yang pertama untuk ditingkatkan adalah variabel disiplin kerja karena memiliki nilai koefisien regresi paling besar diantara dua variabel bebas lainnya, selanjutnya meningkatkan variabel kepemimpinan kepala sekolah dan yang terakhir variabel lingkungan sekolah. (2) Untuk meningkatkan disiplin kerja dapat dilakukan oleh kepala sekolah dengan membuat aturan yang jelas agar tidak mudah dilanggar serta adanya sanksi yang tegas terhadap pelanggaran disiplin kerja. Sehingga akan memberikan kesadaran kepada semua pihak di sekolah terhadap pentingnya sikap disiplin. (3) Diharapkan kepada guru di SMK N 4 Padang agar mengambil nilai-nilai positif dari kegiatan supervisi pendidikan yang dilakukan oleh kepala sekolah seningga dapat memperbaiki hasil belajar dan bila hasil belajar meningkat tentu kinerja guru juga akan meningkat.(4) Untuk meningkatkan lingkungan sekolah dapat dilakukan oleh kepala sekolah melalui kegiatan-kegiatan yang akan meningkatkan kesadaran dan rasa kebersamaan bagi semua pihak disekolah terhadap pentingnya lingkungan yang baik dengan demikian akan dapat meningkatkan kinerja guru pada SMK N 4 Padang dapat dicapai. 


\section{DAFTAR PUSTAKA}

Ali Imron. (1995). Pembinaan Guru Di Indonesia. Jakarta: PT. Dunia Pustaka Jaya. Anoraga, Panji. 2001. Psikologi Kerja. Jakarta: Rieka Cipta.

Anaroga, Panji. 2006. Psikologi Kerja. Penerbit Rineka Jakarta.

Arikunto, Suharsimi. 2006. Prosedur Penelitian Suatu Pendekatan Praktek. Jakarta: Rineka Cipta.

Arikonto, Suharsimi. 2006. Menejemen Penelitian. Edisi revisi. Jakarta ; Rineka Cipta.

Barnawi \& Arifin, Mohammad. 2012. Kinerja Guru Profesional. Jogjakarta: Ar-Ruzz Media.

Darda, M. 2009. Kontribusi Gaya Kepemimipinan Kepala Sekolah Madrasah Dan Motivasi Kerja Terhadap Kinerja Guru Madrasah Aliyah negeri Dan Swasta Se Kabupaten Majalengka. Tesis. Universitas Pendidikan Indonesia. Bandung

Davis \& Newstrom, 1996, Human Behavior at New York, Oganizational Behavior, 8 th Edition, Mc.GrawHill, New Tork.

Davis, Keith \& Newstrom, John W. 1985. Perilaku Dalam Organisasi (Jilid 2). Jakarta: Erlangga.

Depdiknas. (2008). Penilaian Kinerja Guru. Direktorat Jenderal Peningkatan Mutu Pendidik Dan Tenaga Kependidikan, Departemen Pendidikan Nasional.

Devis, Keith dan Newton, Jhon W, Perilaku Dalam Organisasi. Erlangga Jakarta, 1990.

Dharma, S, 2008, Manajemen Prestasi Kerja, Edisi Pertama, Rajawali, Jakarta.

Darmawan, Didit. 2013. Prinsip-prinsip Perilaku Organisasi. Surabaya: Pena Semesta.

Ghozali, Imam. 2007. Aplikasi Analisis Multivariate Dengan Program SPSS. Badan Penerbit Universitas Diponegoro.

Handoko, T. Hani. 2011, Manajemen Personalia dan Sumber Daya Manusia, Edisi 2. 2011. Yogyakarta. Penerbit : BPFE.

Hersey, Paul and Kenneth H. Blancard. 1993. Management of Organizational Bahavior, Utilizing, Human Resource. 6 th edition. Prentice Hall.

Irawan, Prasetya, dkk (2007), Manajemen Sumber Daya Manusia, STIA-LAN Press, Jakarta.

Indrafachrudi, S. \& Tahalele, J.F. 1995. Mengantar Bagaimana Memimpin Sekolah yang Baik. Jakarta: Ghalia Indonesia.

Kuncoro, Mudjarad. 2006. Metode Riset untuk Bisnis dan Ekonomi, Penerbit Erlangga, Jakarta.

Mangkunegara, A.A. Anwar Prabu. 2011. Manajemen Sumber Daya Manusia Perusahaan. Bandung: PT. Remaja Rosdakarya.

Musliadi PNL. 2012. "Metode Pembinaan Disiplin Pegawai". Artikel, (Online), http://musliadipnl.files.wordpress.com/2012/01/, diskses 18 April 2013).

Muzaeni, Ali. 2003. Pengaruh persepsi guru mengenai kriteria kepemimpinan kepala sekolah dan iklim kerja terhadap kinerja guru SMU Swasta di Kabupaten Tegal. Tesis, program Pascasarjana Universitas Negeri Semarang.

Nugroho, Bhuono Agung. 2005. Strategi Jitu Memilih Metode Statistik Penelitian Dengan SPSS. Yogyakarta : Andi.

Nitisemito, Alex. 2003. Manajemen Personalia. Jakarta : Ghalia Indonesia.

Oktaviana, Mustika. 2012. "Faktor-Faktor yang Mempengaruhi Disiplin Kerja Karyawan PT. Hutama Karya Wilayah I Medan". Hasil Penelitian. Program Studi Ilmu Administrasi Negara FISIP Universitas Riau.

Peraturan Menteri Negara Pendayagunaan Aparatur Negara dan Reformasi Birokrasi Nomor 16 Tahun 2009 tentang Jabatan Fungsional Guru dan Angka Kreditnya.

Priyatno, Duwi. 2012. Mandiri Belajar Analisis Data Dengan SPSS. Yogyakarta: Mediakom.

Reksohadiprodjo, Soekanto, dan Handoko, 1992, Organisasi Perusahaan, Teori, Struktur dan Prilaku, BPFE, Yogyakarta.

Ristiana, Nunung, 2012, Pengaruh kompensansi, Lingkungan Kerja, dan Motivasi Terhadap Kinerja Guru SD Kab. Kudus. Semarang. 
Robbin P. Steppen, Perilaku Organisasi, Jilid 1, Prenhallindo, Jakarta, 1996. , Perilaku Organisasi, Jilid 2, Prenhallindo, Jakarta, 2000.

Robbins, Stephen, P. 2006. Prilaku Organisasi, Edisi Kedelapan, Jakarta : PT. Prenhallion.

Rumana. 2010. Pengaruh Kepemimipinan Kepala Sekolah Dan Budaya Kerja Guru Terhadap Kinerja Guru (Studi Analisis Terhadap Guru Sekolah Dasar Negeri Di Lingkungan Dinas Pendidikan Dan Kebudayaan UPTD TK dan SD Kecamatan Cilengkrang Kabupaten Bandung). Tesis. Universitas Pendidikan Indonesia. Bandung.

Sadarmayanti, 2001, Sumber Daya Manusia dan Produktivitas Kerja, Bandung : Mandar Maju. Sastrodiningrat, Soebagio. 2005. Kapita Selecta Manajemen dan Kepemimpinan. Ind-Hill.Co.

Satrohadiwiryo, 2005, Manajemen Tenaga Kerja Indonesia, Edisi 2, PT. Bumi Aksara, Jakarta.

Saydam, Gazali. 2005. Manajemen Sumber Daya Manusia. Jakarta : Djambatan.

Sekaran, Uma. 2006. $d$. New York: john Wilwy \& sons, Inc.

Siagian, Sondang P, 1999, Teori dan Praktek Kepemimpinan, Jakarta: Rieneka Cipta.

Sihombing, Umberto. 2004. Pendidikan Luar Sekolah Manajemen Strategi. Jakarta: PD Mahkota.

Simamora, Henry, 2001, Manajemen Sumber Daya Manusia, STIE YKP, Yogyakarta.

Soekarno dan Indriyo. 2000. Lingkungan Kerja. Jakarta: Bina Aksara.

Sudjana, HD, 2001, Manajemen Program Pendidikan, untuk pendidikan Non Formal dan Pengembangan Sumber Daya Manusia, Falah Production, Bandung.

Sudjana, Metode Statistika, Tarsito, Bandung, 1996.

Sudrajat, Akhmad. 2008. Budaya Organisasi Di Sekolah (Online), (http:// akhmadsudrajat.wordpress.com/2008/01/27/, diakses 22 Januari 2013).

Tukiran, A, S. 2010. Pengaruh Motivasi Kerja, Kepemimpinan Kepala Sekolah dan Lingkungan Kerja Terhadap Kinerja Guru SMP dan SMA Negeri di Kabupaten Banjarnegara. Tesis. Universitas Jendral Soedirman. Surabaya.

Wirawan, 2012. Evaluasi Kinerja dan SDM. Salemba Empat, Jakarta

Zainun, Buchari, 2007, Manajemen Sumber Daya Manusia Indonesia, Gunung Agung, Jakarta. 